Article

\title{
"You Help Them Out and God Gets the Glory": Social Class and Inequality in a Fundamentalist Christian Church
}

\author{
Lindsay W. Glassman \\ Sociology Department, University of Pennsylvania, Philadelphia, PA 19104, USA; E-Mail: Iwglass@sas.upenn.edu
}

Submitted: 31 January 2018 | Accepted: 8 March 2018 | Published: 22 June 2018

\begin{abstract}
Members of Full Truth Calvary Church (a pseudonym) say that they trust God for their material needs by relying on Him to send jobs, homes, and even occasional windfalls of cash. In doing so, they reject steps that might help them get ahead, such as higher education, credit cards, mortgages, or negotiations for higher pay. Members frame their circumstances-which would typically mark them as working class or poor-as indicators of faith. Using over three years of ethnographic and interview data, I explore how this fundamentalist religious community manages socioeconomic risk and inequality with a discourse of reliance on God. I present three key findings. First, I show how Full Truth teachings connect financial practices to faith, framing how members handle money as an important part of their Christian identity. Next, I show how those teachings mitigate inequality by discouraging educational or economic advancement that would place members outside of church community norms. Finally, I show how members with greater means give to their poorer brethren anonymously in an effort to keep the focus on God as the ultimate provider. Though members remain aware of inequity between families, these gifts ideally ease disparities without creating relationships of debt or resentment. My findings contribute to sociological understandings of how religious communities make meaning out of socioeconomic inequality.
\end{abstract}

\section{Keywords}

congregations; fundamentalism; inequality; religion; social class

\section{Issue}

This article is part of the issue "Complex Religion: Intersections of Religion and Inequality", edited by Melissa J. Wilde (University of Pennsylvania, USA).

(C) 2018 by the author; licensee Cogitatio (Lisbon, Portugal). This article is licensed under a Creative Commons Attribution 4.0 International License (CC BY).

\section{Introduction}

Americans are in the midst of a national conversation about social class and inequality. From voting patterns to educational opportunity, sociologists have a tremendous amount to offer the discussion about how class differences occur and what they mean for an increasingly stratified society. What the large, often quantitative sociological studies that address these issues cannot tell us, however, is how inequality plays out in day to day life. What does it mean to be richer or poorer in one's community? What is the larger significance of helping a friend in need, or receiving help from a relative? Religious communities offer a valuable microcosm of such issues, providing a tightly knit social group in which to observe and analyze the steps that individuals take to manage inequality.
Using ethnographic and interview data from over three years at Full Truth Calvary Church (a pseudonym), I show how church members in one fundamentalist Christian community operationalize religious beliefs to mitigate internal inequality and to manage existing disparities without exacerbating social divisions.

Below, I illustrate existing socioeconomic divisions within the Full Truth community and how members manage them. I present three key findings. After illustrating existing socioeconomic divisions within the community, I first show how Full Truth teachings link financial practices to faith by arguing that to truly trust God one must avoid typical financial practices, choosing instead to pray for things like a job, a place to live, and enough money to feed one's family. These alternative practices become a key way that members identify as good Christians. Next, 
I demonstrate that trusting God for finances means that members discourage steps that might help them get ahead, such as higher education, home mortgages, professional networking, or credit cards. By making a religious virtue of modest aspirations, Full Truth members avoid the gains that might create greater inequality in their ranks. Finally, I show that when members do fall on hard times, they rely on anonymous gifts from other congregants, who hide their identity so that the recipient can thank only God for the help. Members thus speak in the language of having received an "answer to prayer", even while acknowledging that a friend or family member has provided assistance. Such anonymous giving eases disparities within the church without creating relationships of debt or resentment. I conclude by briefly considering the ways in which this management of internal disparities may promote solidarity among members experiencing the larger hardships of living as working class Americans and make religious meaning out of the challenges they face.

\section{Background}

A large body of literature examines inequality between Christian denominations in the United States (Demerath, 1965; Niebuhr, 1929; Smith \& Faris, 2005; Wilde \& Glassman, 2016), with studies finding that income (Keister, 2003; McConkey, 2001) and education (Beyerlein, 2004; Darnell \& Sherkat, 1997; Massengill, 2011) are typically highest among Mainline Protestants and Jews, and lowest among Conservative Protestants. Much of the literature on social disparities in the religious context also addresses racial inequality, including studies on the presence of, and attitudes towards, racial inequality and denominational segregation (Cobb, Perry, \& Dougherty, 2015; Edgell \& Tranby, 2007; Emerson \& Smith, 2000; Emerson, Smith, \& Sikkink, 1999; Perry, 2013).

A smaller body of research examines inequality within congregations, with past work suggesting that voluntary organizations, including religious groups, are largely homogenous (Emerson \& Smith, 2000; McPherson, Smith-Lovin, \& Cook, 2001). However, while studies have found that socioeconomic diversity-measured by both income and education-is uncommon, it far outpaces racial diversity ${ }^{1}$ (Dougherty, 2003; Reimer, 2007; Schwadel, 2009; Schwadel \& Dougherty, 2010). Looking at the Christian context, Schwadel (2009) shows that socioeconomic diversity is more likely to occur in churches with higher proportions of high-income and college-educated members, as well as in churches with stable memberships. Conversely, churches with more low-income members or those without a college education are more likely to be homogeneous, as are congregations that are newly founded and/or growing in membership. Largely because of these latter attributes, conservative Protestant churches are especially likely to be socioeconomically homogeneous, a characteristic that is born out in this study. ${ }^{2}$

How churches address inequality within their own community is another question. Wuthnow (2003) finds that the religiously involved are slightly more likely be friends with members of historically disadvantaged groups, including racial minorities or those using government assistance programs. This finding is important in light of past research showing that inter-status relationships create less social distance and more social benefits between groups (Yancey, 1999). However, these findings are largely a product of who is already a member of the congregation-Wuthnow (2003) finds that mainline Protestants and Jews, who are typically high status, are least likely to have friends from disadvantaged backgrounds-meaning that those befriending lower status members may be of only somewhat higher status themselves, and suggesting that religious membership does not automatically push members to reach beyond their own social class. More broadly, disadvantaged members are at risk for feeling alienated from their brethren. For example, Sullivan (2012) finds that some of the most disadvantaged women leave faith communities despite their continued personal religiosity, feeling unwelcome in congregations whose members are judgmental of their lives as single mothers or welfare recipients. And while Schwadel (2002) finds that lower status church members may gain skills of civic engagement and political participation from their higher status compatriots, positions of leadership remain highly stratified, limiting the benefits of cross-status relationships.

Most existing scholarship looking at religion and charitable activities focus on religious members' involvement with recipients outside of the congregation. In his comprehensive study of congregations, Chaves (2004, p. 48) finds that, though $57 \%$ of religious groups engage in some kind of social service, most do so in discrete, direct interventions like food or clothing donation, or by partnering with larger secular organizations, like Habitat for Humanity. These services are rarely targeted at members within the church's own community. Chaves shows that churches located in poor neighborhoods, but with a largely middle-class membership, are most likely to offer social services. Churches with poorer membership

\footnotetext{
${ }^{1}$ For example, recent findings show that just $7-8 \%$ of religious communities are multi-racial, meaning that no one racial group comprises more than $80 \%$ of the congregation (Emerson, 2000; Emerson \& Woo, 2010; DeYoung, Emerson, \& Yancey, 2004). Certain factors do increase the likelihood of racial diversity, however: Urban congregations are more likely to be racially diverse than those in rural areas (Dougherty, 2003; Dougherty \& Huyser, 2008; Emerson \& Woo, 2010), and Catholic parishes, which draw from neighborhood catchment areas, are more racially inclusive than their more segregated Protestant counterparts (Dougherty, 2003; Dudley \& Roozen, 2001; Schwadel, 2009). Congregational attributes influence racial integration, including the presence of diverse leadership, small group meetings, charismatic worship style, intentional diversity outreach, and proximity to integrated neighborhoods (Dougherty \& Huyser, 2008; Emerson \& Kim, 2003).

2 Interestingly, some find that churches with higher racial and ethnic diversity are simultaneously more likely to be socioeconomically homogeneous, with a shared (usually high) class status bridging racial divisions (Ammerman \& Farnsley, 1997; Dougherty, 2003). Others, however, dispute this finding, suggesting that racial diversity can be linked to socioeconomic diversity (Yancey \& Kim, 2008).
} 
are less likely to offer services, regardless of the socioeconomic circumstances of the surrounding area. Overall, studies find that religious individuals are significantly more likely to volunteer and donate money to charitable causes than those who do not identify as religious (Brooks, 2003; Gittell \& Tebaldi, 2006; Havens, O'Herlihy, \& Schervish, 2006), and that religiosity, rather than denominational affiliation, matters most for giving (Regnerus, Smith, \& Sikkink, 1998).

When thinking about inequality within congregations, it is also helpful to consider what religious institutions teach about the spiritual meaning of wealth, and the proper use of money among the faithful. Perhaps the most famous theory about the connection between religion and economic behavior is Weber's Protestant Ethic and the Spirit of Capitalism (1930/2002), which links Calvinists' quest for positive signs of their predestination with profit accumulation and prudent investment. Today, scholars continue to find that the values of Protestantism-particularly a personal relationship with God-encourage individualistic perspectives on economic pursuits and success (Barker \& Carman, 2000; Chusmir \& Koberg, 1988; Schaltegger \& Torgler, 2010). Relatedly, proponents of the "prosperity gospel" argue that God will provide health or wealth to those who pray for it (Schieman \& Jung, 2012). Though, as Souders (2011) has pointed out, prosperity theology purports to give believers greater agency in their own success by aligning religious effort with financial effort, it differs from the Protestant Ethic in stressing faith and prayer over labor as the key mechanism behind economic gains.

Ultimately, though sociologists of religion have examined racial and socio-economic stratification between denominations, and even between congregations, we know little about inequality within congregations. Furthermore, while past work has looked at the propensity of religious individuals to give money to people outside their congregations, little work addresses how communities handle internal inequality, nor how the presence (or absence) of material wealth fits with religious doctrine at the congregational level.

\section{Methods and Setting}

The following study is based on over three years of ethnographic observations at Full Truth Calvary Church, supplemented with interviews and analysis of church literature. Between March 2014 and May 2017, I attended one to two church services per week (of three total), and developed relationships with seven extended families. Within those families, I spoke with about fifteen people frequently, and spoke occasionally with an additional eighteen. Services lasted about an hour and a half, and I spent time before and after the service chatting with congregants. I also spent time with members outside of church services for social outings like miniature golf, carol singing, and Christian music concerts, as well as at events like bridal showers, Christmas parties, and women's fellowship nights. In total, I spent more than three hundred hours with church members and came to consider many members friends.

In addition to ethnographic observations, I conducted ten formal interviews with church members and eight formal interviews with former church members. Of the members I spoke with, seven were women, three of whom were married. All were white, and between the ages of nineteen and sixty. Of the three male church members I interviewed, two were married and one was widowed. One male respondent was black and the other two were white, and all were between the ages of forty and sixty-eight. In addition to those members, I spoke with five women and three men who have left Full Truth. The women were all white, and between the ages of thirty-seven and sixty-six. All but one were married. The men were all married and between the ages of forty-one and forty-nine.

I recruited interview participants through the social network that I developed at the church, striving to represent a diverse sample of adult congregants. I found that despite close relationships with a number of members, most were very hesitant to participate in formal interviews. Many claimed that there was "nothing special" about their experience, and despite assurances that all experiences were interesting and worthy of an interview, I suspect that most continued to be uncomfortable because of broader concerns about privacy and publicity. ${ }^{3}$ Ultimately, only one-third of members I asked agreed to be interviewed. Fortunately, however, the ten people who did agree to be interviewed represented a diverse cross-section of the congregation. Several of my earliest interviews were with members introduced to me by the pastor, and I considered them institutionally sanctioned as exemplary congregants: friendly, articulate, secure in their faith, and, as I later learned, members of the wealthier and more socially prominent families. I received referrals to three other members from my initial participants, and these new respondents widened the age range and number of families with whom I spoke, but kept me still within what I would consider the core church community. The remaining participants, however, were drawn from my own relationships with church members, who were much less centrally located in the social life of the church. This is not to say that they were marginalized, but I was grateful to get the perspective of members who were not connected to those recommended to me by church leaders.

I decided to interview former church members about a year into my ethnography at Full Truth. I sought out former members to provide a different perspective on life in the church and to better understand why members decide to stay or leave the community over time. I also hoped that former members would share their thoughts

\footnotetext{
${ }_{3}$ This group has received past media coverage for their medical beliefs, which some members perceived as negative. These experiences added to an already insular attitude among members to create an intense desire for privacy.
} 
on inequality in the church community, and that they might be more candid than current members, whom I found to be reticent on questions of socioeconomic disparity. Though all former members were critical of the church in some respects, most were not angry or bitter about their experiences there, and all continued to be in at least limited contact with family members who remain in the church. ${ }^{4}$ However, I avoided publicizing my contact with former members while among current members, as one current member told me that she suspected people would begin to "shut me out" if they knew I was speaking with former members, fearing that my goal had been to publish harmful things about the group all along. This was of course not my intention, but I was sensitive to how my interest in speaking with former members could be perceived and kept that interest private from all but a few close, discreet contacts at the church. I ultimately recruited three former members who attended family gatherings thrown by current church members (and at which I was present), and all others through snowball sampling from those initial three former members.

Finally, I reviewed approximately one-hundred church pamphlets from the 1990s through the present. Pamphlets were summaries of recent sermons that were mailed to members every other week throughout the year. I received these pamphlets at my home, and also collected older pamphlets from a display at church, and from members who were willing to share older pamphlets stored in their homes. These pamphlets were helpful as distillations of church teachings and as succinct reminders of recent themes that members heard in services.

I coded all fieldnotes and interview transcripts using Atlas TI software. I developed a code scheme for employment and financial data, focusing on members' beliefs about money, God's role in material well-being, employment history, and charitable giving. Coding was an iterative process, in which I used early interviews and observations to hone my codes, and revisited early data to apply later insights. I went through a similar process for church pamphlets, but chose to code them by hand.

Before presenting my findings, it is important to briefly describe Full Truth to provide context for my data. Full Truth Calvary Church was founded in 1925 by a man named Julius Burke. Mr. Burke started the church as a separatist faction of another non-denominational Christian church called First Christ Chapel. His small congregation was located in a working-class neighborhood of a major city, close to First Christ Chapel.

From the start, Full Truth was a strongly fundamentalist congregation, part of the conservative Christian movement that emerged in the 1920s in opposition to increas- ingly scientific worldviews. Leaders relied, as Marsden (1991) has argued all fundamentalist churches do, on the forces of modernity to serve as a foil for their teachings. For example, by framing modern society as morally relativistic, Full Truth leaders emphasized a literal, unchanging interpretation of Biblical morality. ${ }^{5}$ Decrying changes in education and government assistance policies, Pastor Burke insisted that members trust God for the material and financial elements of their well-being.

Today, Full Truth Calvary Church retains most of its original, defining beliefs. Melvin Burke, a grandson to Julius, is the current pastor, and continues to preach the message of trusting God that his grandfather stressed nearly a century ago. Members continue to stress personal faith and Biblical literalism over proselytizing. Though the congregation has moved its operations to different buildings over the years, it remains in the working class, urban neighborhood of its founding. Full Truth has about five-hundred members, including children, and the congregation is overwhelmingly white. The community is split relatively evenly between men and women, with the oldest members in their mid-eighties.

However, in important ways, Melvin's leadership signals a new direction for the church: he prides himself on comfort with technology, texting rapidly and posting photos on social media platforms like Instagram. Furthermore, while most church members continue to avoid television and secular music as they did in the twentieth century, many note that Pastor Burke is more accepting of modern entertainment than were previous generations of leadership. Though members have always worn typical modern clothing, older members feel that the norms of modesty are in some cases loosening among the younger generation.

Children attend a church-run school, which extends from kindergarten through tenth grade, after which point youth are legally permitted to leave school. Most graduate from the church school (though they do not receive a state-sanctioned high school diploma), and begin the process of praying for a job, which I describe below. Typical jobs for young men include construction, plumbing, or short-haul truck driving, while young women often work in food service or retail until they marry and begin having children.

As a matter of trusting God for healing, all forms of modern medicine remain strongly discouraged, including methods of contraception. As a result, families at Full Truth are quite large-most families have at least seven children, with twelve, or even sixteen children not uncommon. In addition to restrictions on contraceptives and pharmaceutical drugs, church members also refuse seatbelts (insisting that one should trust in God for pro-

\footnotetext{
${ }^{4}$ Full Truth members vary in how much they will communicate with family and friends who leave the church. Some stay in frequent contact, continuing their previous relationships. Most keep in more limited contact, by, for example, remaining connected on social media but speaking only at holidays and birthdays, if at all. A few people told me that they had completely severed relationships with former members, but even these members typically continued to be aware of the welfare of their ex-friends and family members through others' contact with them.

${ }^{5}$ I characterize Full Truth Calvary Church as a fundamentalist group because they combine an emphasis on Biblical literalism with an aversion to proselytizing. While evangelicals might share their literalist Biblical teachings, Full Truth members differ in their de-emphasis on spreading the gospel. Instead, members feel that they must make themselves as perfect as possible to be ready for God and the Second Coming of Christ.
} 
tection in the case of a crash), as well as prescription eyeglasses and dentistry, though members do practice oral hygiene.

In contrast to many conservative Christian congregations, Full Truth services do not feature a charismatic leader, emotional music, or group prayer. Instead, the tone of sermons is reserved, and only the pastor and assistant pastor speak (except for one prayer at each service, which is led by one of a handful of respected older men in the community). Outside of church, members tell me that they pray, typically apart from even their own families, except for mealtimes or prayers with small children. Youth receive their own Bibles around age thirteen and are encouraged to read and pray alone in the morning and evening. Thus, members' choice to trust in God for things like good health and financial well-being is largely a private one, though the close-knit nature of the community means that members are aware of each others' choices and circumstances.

\section{Findings}

I find that members of Full Truth Calvary Church draw on religious beliefs to mitigate inequality within the community. Members' insistence on trusting God for financial stability means that they discourage higher education, salary negotiation, loans, or other tactics that many Americans use to get ahead. Though some members are more financially successful than others, the wealth gap remains in check as a matter of religious principle. Furthermore, I find that members use anonymous gifts to one another in the form of cash, food, and goods, to help those in need while encouraging the recipient to thank God instead of an individual. The practice of anonymous giving is another strategy that reflects religious beliefas members feel that their faith in God has been rewarded through the gift-while preventing relationships defined by debt or a division between the "haves" and "have-nots" of the community.

\subsection{Inequality at Full Truth Calvary Church}

Members of Full Truth Calvary Church are predominantly working class, with some older or single members slipping towards poverty. Though respondents uniformly refused to give me specific income numbers during interviews, I was able to gather clues about members' earnings from informal conversation and observations. Most lived similarly in small rowhomes with three or four bedrooms and one bathroom. With families so large, it was common for there to be one boys' room and one girls' room, sometimes with several triple-stacked bunkbeds in each. Single adults lived with either parents or siblings, often in duplex apartments. Everywhere that I visited, I found that homes were well cared for, with lots of family photos on the walls, overstuffed sofas, and gleaming table tops. Surroundings were never opulent, but members' proficiency in home repair work meant that they were able to maintain houses well, often earning the appreciation of landlords only too happy to have someone else keep up the property. Though members did not negotiate for lower rent as a result of these repairs, several told me that their landlords had not raised the rent in many years, a decision that they attributed to God's providence.

Inequities stemmed from members' occupations, with carpentry and cabinet-making being the most lucrative. Several families shared businesses between brothers or cousins, often extending work to younger relatives (typically, but not always, young men) as they got older. Notably, education was not a source of disparity, as almost all members attended the church school, but certainly members of the business-owning families were more likely to receive valuable training. Members with fewer direct connections to these families were visibly poorer in subtle but important ways. For example, though all church members wore their "Sunday best" to services, I noticed a handful of people who wore the same dress or suit every time, while others rotated through colorful styles that I recognized from inexpensive chain stores like Target. Similarly, some members drove freshly painted vans with the name of family businesses emblazoned on the side, while others used vehicles pocked by rust. Again, the differences were not extreme-no one appeared to be driving a car that was even new, let alone an expensive brand-but members of families with thriving businesses stood out as living more comfortably than some of their brethren.

Inequality was not something that current members acknowledged to me, and it took me over a year to understand that disparities in wealth translated to social distinctions more broadly. An ex-member and mother of nine, Casey Miller, was the first to spell out the hierarchy of families for me:

There's a pecking order, and the Schroders and Hoffmans are it [at the top]. The Millers and Scotts are kind of-well, hold on, [there are] the Harold Scotts, Becky Schroder Scotts, and Gretchen Miller Scotts, they're right below the Schroders and the Hoffmans. And then you have the Ecklunds and the Millers, and then below them are the Reids and the Pattersons and the Browns.

I was frankly surprised to hear such a clear hierarchy articulated by Casey, largely because I had not perceived marked social distinctions at the family level. Certainly, I had noted that some individuals were more or less popular, appeared to have more or less money, or seemed more or less integrated into the church leadership (for example, a handful of more prominent men rotated in leading a prayer at each service, the only time anyone spoke during services except for the pastors). But Casey could describe the status of each family in detail, down to the branches represented by individual people who had married into certain prominent families from other promi- 
nent families (i.e., the "Becky Schroder Scotts"). She declared that the Schroders in particular were "always able to keep clean" despite a number of community scandals, including an instance of one son who was known to be having relationships with men while married to his wife. She noted that her new church, an evangelical Christian congregation in her neighborhood, felt less marked by social distinctions, and contrasted her positive experiences there with her time at Full Truth: "Where we came from, there were a lot of strings attached. You could fit in with the Schroders, as long as you didn't mind them calling the shots and them paying the bills". As Casey described it, the Schroders' greater wealth was directly connected to their ability to influence church life.

Though no current members described the social hierarchy to me in such stark terms, many gave me detailed family tree information in the way Casey had, complete with information about intermarriages several generations before. One young woman, however, a lifelong member of Full Truth named Hannah Scott, quietly confided in me one day about her social anxiety around her upcoming wedding to a man from a less popular family. In my fieldnotes, I recorded our exchange while we stood chatting in the parking lot outside the church after one Wednesday evening service:

I ask Hannah what her new last name will be, and I notice that she looks a little surprised that I don't know Kevin's [her fiancé's] last name. Her eyebrows go up just slightly, though not unkindly. "Patterson", she says. "Hannah Patterson". "That sounds great", I say. Hannah looks off at the chatting crowd, quiet for moment. Then she says: "You know, it's silly, but I had to make peace with having that name. Growing up-I think this is the case in any group-but with our [church] group, in school, the Pattersons were a family that would get teased a lot. You know, kids can be cruel". I ask what they would get teased about, and she shakes her head, "Nothing, really, there wasn't a specific reason. It was like, 'They have cooties!' and stuff like that. But I realized that I had to get over that, because I still had it in the back of my head. You can see God's grace right there, because He took away those feelings, and I know now that it really doesn't matter".

Though Hannah did not describe it in these terms, I knew that the Pattersons were not one of the families with higher incomes, their own businesses, or marital connections to church leaders. Patterson men were not among those who led a prayer during each service. In Hannah's telling, these distinctions in status were visible to her as early as the school playground, where children seemed to understand that some families were deemed less worthy of respect. Though I knew Hannah's fiancé as a kind and friendly man, I came to see that he was indeed not part of the inner circle of young men from families like the Schroders, Hoffmans, and Scotts. Hannah felt that her faith had enabled her to move past her concerns about social stigma and now feels that it "really doesn't matter". Indeed, as I show below, religious beliefs directly ameliorate inequality in this community, lessening tensions that might otherwise threaten a small, tightknit congregation.

\subsection{Faith in God the Provider: Financial Choices as Religious Practice}

Members of Full Truth Calvary Church emphasize that true Christians must trust God for all aspects of their well-being, including health ${ }^{6}$ and material needs. They argue that God provided for people in the Bible because they had faith in Him to do so. Thus, to rely on financial safety measures, such as savings accounts, retirement plans, or insurance policies, places trust in human institutions rather than God. Furthermore, to take steps that improve one's own financial position-through, for example, higher education or aggressive salesmanship-is a sign of insufficient faith. A church pamphlet outlined the message succinctly:

A genuine surrender to God is a total commitment to trust Him.... If we are committed to doing God's will in finances, we will not purchase anything on credit, and will not hint to anyone that we need anything. A total surrender like that will place God at our side and enable us to access His huge financial resources.

Another pamphlet said similarly:

God controls all financial resources in Heaven and $\mathrm{He}$ wants to supply every financial need for those trusting Him on earth....When we present our needs to God in prayer (and keep that between us and Him only), He promises to supply every need from His resources in Heaven. We should not knowingly place ourselves in debt by borrowing money, making purchases on timepayment plans, or using credit cards for things that cost more than the cash we have at that present time.

Trusting in God means relying on Him for ongoing care, so the accumulation of savings or a financial safety net are viewed as placing trust elsewhere. Members are also discouraged from letting others know of their needs, suggesting that requests for help signal insufficient faith. Notably, keeping one's money trouble private also lessens the social strain of asking friends and family for loans, particularly when those one would ask might be facing tight budgets themselves.

One result of abiding by the Biblical injunction to "not lay up treasure on earth" (Matthew 6:19) is that members do not own property, choosing instead to rent for years on end. Many families have rented the same modest homes for over thirty years, making improve-

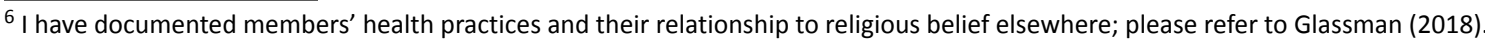


ments to the property while paying their rent diligently. Furthermore, because members will not accept government assistance of any kind, church-owned businesses have been granted exemption from paying social security taxes, with the recognition that members will not accept social security payments later in life. The result, however, is that members can amass little in the way of wealth.

Full Truth members also refuse insurance because it provides a financial safety net that members believe should be provided by God. Avoiding health, dental, or renters' insurance is their prerogative, but car insurance is a somewhat trickier issue, as it is required to drive legally. Wilson Schroder, a 68-year-old cabinet maker, father of thirteen, and grandfather to over forty, explained how church leaders developed a workaround that allows members to have insurance without violating their beliefs:

The situation [with] cars came down in 1974, when [the government] came up with this compulsory nofault insurance law, which said everybody had to have insurance. Leaders of the church made a deal with a rental company where you take the title to them, sell them a car for $\$ 50$ and they'll insure your car and you just keep on driving....Melvin [the pastor] feels that if I go into a car rental, they're buying the insurance and I'm not buying it. It's a technical difference.

The technicality of who provides insurance in this case allows members to obey the government while adhering to their beliefs. Though the end result is that they drive with insurance like anyone else, the practice reveals how members' concerted effort to avoid financial protection can have religious meaning even when they ultimately follow social (and legal) norms.

Trusting God to provide for one's financial well-being means not only avoiding certain behaviors, but consciously replacing them with prayer. At Full Truth, members insist that one ask only God for material things or services, including a raise in pay, new appliances, or a difficult home repair.

Perhaps the most important way that God assists members financially is with the provision of a job. Members insist that actively seeking a job demonstrates one's lack of faith in God to provide employment, and smacks of the "self-life" or "self-efforts". Finding a job must be God's will. Jim Miller, a father of nine young children, explained his thinking on finding a job as we talked after Sunday morning service one sunny summer day:

Well, with a job, when we finish school we'll usually pray about it and ask God what we should do. And then the first job that comes up, we usually take it because we see that as a sign that God has sent that job. And if the job doesn't work out, really, or if we don't like it, we don't just quit; we pray about it and try to make it better. It's a little different than how most people do it, but we really feel that it's right.
Thus, anyone in need of a job is taught to pray about it, and to know that the first job to be offered is a gift from God. Rather than weighing the pros and cons of the offer, members insist that the job should always be accepted. If it turns out to be a poor fit, members note that something at the job was likely intended to be a lesson from God. For example, Lewis Huber, a 64-year-old widower with two sons, described the process that he underwent to find a job after he graduated from the Full Truth school:

First was getting a job after I got out of school, and humbling myself and being willing to accept what God had for me to accept, and not accepting anything that wouldn't be obtained in a way that I know is pleasing to Him. Even though I really wanted to do some kind of electronics work, it didn't work out for me. I mean, I was actually told of a place where they were hiring people to do that type of work, but it wasn't a direct offer. We believe in word of mouth. In other words, the Lord inspires someone to bring to your attention that a job is available at such and such a place, a person needs somebody to come work. Not just going by signs on buildings or that sort of thing.

Lewis described a particularly strict form of job hunting, in which members feel that something must be directly offered. Among younger members, I found a more lax attitude towards job applications, with several young people telling me that they were willing to apply for a job if there was a "help wanted" sign in the window. In either case, however, Full Truth members understand the process of finding a job as an exercise in faith.

\subsection{Evening the Playing Field: How Religious Practices Mitigate Inequality}

Though Full Truth members are encouraged to work hard, church teachings discourage members from advancing too much, either professionally or financially, arguing that workers should be content with what they have. In effect, these teachings mitigate inequality directly and indirectly. Some, like Wilson Schroder, the prominent church member noted above, simply avoid expanding an otherwise successful business, choosing instead to keep it family-run. He explained how his cabinet business has remained successful since the 2008 financial crash:

[After 2008], one by one cabinet shops were closing up, but our business always stayed busy and we're very thankful for it. We didn't feel that it was anything that we were directly responsible for, but we felt that the Lord provided the work for us.....We stay humble; we give God all the glory for any success we have, and it's the way we think we should do it.... And yeah, it's worked out well. We run a nice sized shop up there; we have no interest in expanding the business. It provides a very nice living for us, and everything has worked out well. 
Though I later learned that Wilson's business has been lucrative (which I discuss further in the next section), he downplayed its success, framing the shop's continued work in religious terms.

For others, church teachings more directly influenced their work trajectory. Lewis told me about how his initial interest in electronics repair was altered by his future at Full Truth:

I had gotten a job someplace that did repair work with televisions, and they did work for other things like radios and all that, which were fine. But I realized that our church completely objected to television, and I was working somewhere that did television repair work. So, since I knew I wanted to get baptized and accept the teachings, be accepted in as a member, I said, "They're probably not gonna want somebody if they know the occupation I'm in, if this is something I know they're against, and it's against God and the way we should live". I thought that they would not be willing to baptize me. And I had learned enough to know that baptism was required by God to enter heaven. So I decided to leave that job.

Though he had attended Full Truth all his life, when Lewis contemplated becoming a full-fledged adult member through baptism, he understood that his employment could be seen as "against God". Lewis decided to leave the job because it required that he work with televisions, which church leaders prohibited at the time (members today generally still reject television, though most watch Christian movies and PG fare on iPads or computers). An important side effect of his choice, however, was that he left work with presumably higher earning potential and opportunities for advancement. Instead, Lewis went on to tell me about how he repaired radios for a time, before finding that the work was too inconsistent. Eventually, he went to work as a local truck driver, an unskilled position that didn't make use of the training he had received in electronics repair.

Another way that Full Truth members contribute to socioeconomic equality is the practice of bringing family and friends into their workplaces, facilitating "word of mouth" and other seemingly spontaneous job offers. For example, Kathleen Scott, a 40-year-old single woman working as an office manager, recounted how she found her current job after years of taking care of the cooking and cleaning at home while her younger siblings worked:

I kept feeling this restless feeling, like I was ready for a change. But I was like, "God, you know what's ahead, so I'm just giving it to you; just show me what you want me to do next". So then it came to Christmas time, and where I work now, my other two sisters were already working there-Janie and Hannah-and Hannah invited me to come to their Christmas party. So I went, and then the president of the company came over and met me, and it was all well and good, and then the party was over, Christmas was gone. And then it comes to March, and Hannah came home from work one day and...says that her boss came up to her at work and said, "Is your sister Kathleen working now?" and she's like, "No, she's not", and he's like, "Because this position is opening up"....He's like, "I met your sister back at that Christmas party and I think she seemed like someone who could do the job". So it was just like God orchestrated all that all along. So I went in for my interview and then right away they're like, "You're hired!" [laughing quietly as if still in disbelief].

Note that Kathleen defined her job as orchestrated by God, even though her sisters introduced her to their boss and then facilitated her interview when he mentioned a position opening. However, framing the story in these terms reinforces members' belief that God provides for their well-being and de-emphasizes the role of family members in securing employment. As such, Kathleen did not feel beholden to her sisters, but rather was grateful to God for answering her prayer.

Leah Schroder, a twenty-year-old woman living with her parents and six younger siblings, recounted a similar story. Her grandfather is Wilson, quoted above, and he helped her find work in his cabinet business:

When I graduated, I didn't have a job for about two years. Last May, that's when I first started working. And at first they needed the small things done [at the cabinet business], whether it was vacuum up the floor or get the bathrooms cleaned. And then eventually it was like, "Well, you could try doing this if you want", and then I would get it. So it'd be like, "Well, if you could do that, then maybe you could do this or that". So, gradually, they pretty much will teach me anything that they think I could do. I felt like that was God as well, because for the longest time...I wanted to have a little bit more of a schedule. And I just started praying that God would send me something - and that's when I started going in a couple days to do it, and then it started to be full-time.

Leah viewed her job as coming from God, even though her grandfather's company hired her for odd jobs, and then full-time work. From one perspective, such apparent nepotism would seem to create the potential for inequality between families, as some, like Wilson's, are more successful than others. The point is not that there is no inequality between Full Truth families, but that their beliefs provide a narrative that both mitigates its occurrence and lends meaning to the process of finding and keeping a job. Regardless of their family's position, members frame employment as part of one's relationship with God, which de-emphasizes the role of social connections in wealth, and dampens potential tensions over inequalities within the community.

Church leaders commented directly on faith in the workplace, encouraging diligence but also warning 
against measures that might advance members' position or pay. The effect was that members learned to check their aspirations, stymying inequality in the congregation. My fieldnotes captured a typical message about employment, written after one summer Wednesday night service:

Pastor Burke says that we "should always remember that we're working for God" ....Worldly workers will try to "get away" with anything they can-"take unscheduled breaks, take as much time off as they can", whereas members should "only take the scheduled breaks", and work hard for all of your hours, even if worldly workers "take personal calls" or "search for personal things on the internet". Burke also says that worldly workers will always go for more responsibility if it means higher pay, but that members shouldn't do that: "As Christians, we should be seeking to pray at every step of the way-if we're offered more responsibility we should pray about it and decide if that's what God wants us to do". He continues: "If Jesus asked you to do something you would work diligently....You would give it your all, and that's how we should treat our jobs".

Pastor Burke framed work as serving God, which is in many ways an extension of members' beliefs: if the job is God-given then one can logically serve God by performing it well. Such a mindset gives religious meaning to jobs that might otherwise be tiring or dull. However, church teachings also discourage members from accumulating too much wealth or responsibility, encouraging them to think instead in terms of God's will. Indeed, trusting God for work means that church leaders are against labor unions. My fieldnotes summarized a message from one sermon:

Pastor Burke says that while labor unions do help workers get fair wages, they are the worst form of "using human means" to improve a situation rather than "God's way". Thus, unions are not to be joined because they represent "human efforts" in supplying oneself and one's family with material things rather than relying on God.

By refusing to participate in unions, members not only reject the potential for higher pay, but also avoid membership in institutions that might compete with the church for their time and money. Furthermore, members do not face the internal divisions of those working for a union vs. non-union shop-which could contribute to inequality in the community-while maintaining their loyalty to religious leaders over secular union representatives.

Finally, it is important to mention that in addition to leaders' commentary on finances, they have also arranged the church space to discourage visible inequity. While most congregations publicly pass a collection plate-tacitly encouraging congregants to contribute as much as possible out of either shame or pridedonations at Full Truth are submitted at the believers' discretion in a locked box at the back of the church, which is shielded on both sides by privacy screens. Several members told me that it is typical to tithe $10 \%$ of one's income, and it is likely that the Pastor is aware of those who are paying more or less than the designated amount. However, members cannot know what amount others have donated, or whether they have donated at all. The absence of a public tithing ritual is notable for the way it diminishes public displays of means between members.

\subsection{Managing Inequality: Religious Meaning and Charitable Giving}

Of course, Full Truth members are not perfectly equal, and at any given time some are experiencing hardship. In addition to financial support from employment, members rely on God to provide extra help in times of need. This assistance, though believed to be orchestrated by God, is physically performed by members who may provide childcare, eldercare, home repairs, furniture, groceries, or money to a believer in need. Whenever possible, members strive to remain anonymous in these instances of assistance as a way to highlight the role of God in the matter. Perhaps more importantly, anonymous giving prevents the development of debt relationships between members and lessens inequality without developing a hierarchy of "haves" and "have nots".

Alice Ecklund, a single woman in her late thirties who works in food service, summarized Full Truth teachings on the matter:

When you know someone needs something you're gonna do everything you can to make sure you help them out and God gets the glory. That's what's important to all of us, that it's not us glorified but God. We don't want to say thank you because how can we say thank you to the one who gave us our ultimate gift [of salvation]? That is what's important. We all feel that way, I hope. I mean, everybody that I know feels that way.

She went on to describe a recent example of how she helped a couple who needed furniture when they found a new home to rent. Her story demonstrates the lengths to which members will go to hide their role in the gift, and how shared beliefs about giving operate to obscure the sender:

For Lana and Bill Graf, when they moved into that home over there, they didn't have money for furniture, [so] I went to a furniture store over here that was going out of business and paid [for] a whole new living room set...and I put a note in the offering box. What you do is you put a note in the offering box. Say, for instance, I put a note in there addressed to my friend 
Rosemary: "Rosemary, I bought furniture for Lana and Bill, paid in full, but they're gonna need a confirmation on a phone number". You know, because your first impulse when you get a delivery like that is to reject it....So you'd write a note to someone in church [and] they would be your backup person so they get the note and they know that someone blessed this other person anonymously.

Importantly, the friend, Rosemary, who received Alice's note in the offering box understood what was happening. When the pastor opened the offering box, he saw a note addressed to Rosemary and passed it on to her, who was then able to help execute the gift without knowing who sent it. In this case, Lana and Bill saw on the delivery slip to call Rosemary, who could then confirm that the furniture was from a Full Truth member, while telling them truthfully that she did not know who had sent it. Members who receive gifts anonymously are unable to thank any one person, or, perhaps more importantly, to begin thinking more highly of that person than others. Anonymity thus serves to strengthen faith by encouraging members to view God as the source of all gifts because He has "put it on the heart of", or inspired, a person to assist.

Kathleen, the woman described above who went to work with her sisters, explained what it's like to be on the receiving end of this anonymous help. She recounted a dark time about twenty years ago, after both of her parents passed away within a month of one another. Kathleen, just twenty-two at the time, faced both grief and the daunting prospect of raising most of her nine siblings. At Christmas, only a few months after her parents' deaths, an aunt invited all ten siblings to stay for the week. Unbeknownst to them, while they visited their aunt other members collaborated to re-carpet Kathleen's family home as a gift:

Kathleen: We ended up staying [at my aunt's house] for over a week, and while we were gone somebody put new carpets in our whole house.

Interviewer: You still don't know who?

Kathleen: No! Because like, if they're in the church, they would do it anonymously so God gets all the glory. So we were just told, "Well, somebody wants to put new carpets in your house so you can just stay [with your aunt] for however much longer".

Kathleen echoed Alice's description of how members offer help anonymously so that the recipients thank God. The carpet was a gift intended to brighten their home in the wake of tragedy. Though it might seem more logical that members would provide money, Kathleen noted that several siblings were already employed, and had been largely supporting the family as their parents fell ill. Kathleen remembered the gift of new carpets fondly as a time that she felt embraced and cared for by what she termed her "church family".

Others, however, did recount the experience of receiving cash when they needed it. Suzanne Graf, a sixtyyear-old mother and grandmother, told me about one such time:

I wanted a new window because the other two windows were not even sealed around them, they were very old. I had mentioned to my husband, "Wouldn't it be nice to have a new window?" So we talked about it, and everybody knew mom wanted a window....[But] I'm not a nagging wife, I'm not the type...I just said, "I'm not gonna say anything, I'm just gonna ask the Lord". And I just said, "Lord, you know we need a new window"...and I prayed a couple months and I said, "If it's your will, would you send us a new window?" And [one day] there was an envelope on my seat at church with $\$ 1,000$ in it that said: "For your new window". And I said to my husband, "Why would they send it to me and not you?" You know? But I was the one who was praying for it, I was the one who was asking for it.

Suzanne interpreted the gift as from God because it was given to her rather than her husband, who, she told me, made all their financial decisions. Because she had been praying for the window, she framed the money as an answer to prayer, despite what seems to have been widespread knowledge that she wanted a new window.

Members also believe that gifts are at least partially the direct result of their own faith. In that way, members can feel that their gifts have been "earned" by their trust in God rather than received through charity. Jeremy Schroder, age forty-three and father of seven, explained:

The Bible tells you that if you tithe, you'll be blessed 100 times [over]. So you've heard how the Bible says to give to those who ask. Well, every Sunday we get the same guy on the corner [asking for money]....So every time I've given the guy 5 bucks have I gotten $\$ 500$ ? No. But it's there. And if you had perfect faith, you would be getting $\$ 500$ back. Because He tells you that.... But certainly there's been many times, like I said, just recently I went by my friend-I call him my friend, on the corner-and I think I gave him 5 bucks or whatever, and when I got to church, there was an envelope for me and it had $\$ 400$ in it.... Now you could say, "Well, someone did that" - [and] you're right. But someone had to be inspired to leave it to me first.

Jeremy went on to explain that he had been praying for money to be able to take his family on a vacation. He understood the $\$ 400$ to be a gift from God in answer to prayer, even though he acknowledged the role of a church member in providing it for him. With that money, Jeremy's family was able to join others from Full Truth on their annual trip to a local beach, mitigating what might 
otherwise have been an experience of financial hardship and inequality vis-à-vis other church families.

As the above quotes illustrate, members are aware that the gifts they receive come from other membersall stressed to me that they do not believe that things have miraculously appeared from God. However, they strongly feel that God has inspired that person to give the gift. Some also detailed to me how they can be an instrument of God in providing help to others. Alice, who earlier recounted the process of anonymously gifting living room furniture, also described how she has operated as a go-between for others seeking to help an elderly female church member:

Miss Brenda, she works one day a week; she doesn't have money to pay for groceries. There's been times that people have dropped groceries off at my house to give to her. And I know there's also times that she's come home from work and found groceries sitting on her porch.... One time I went there and she didn't have toilet paper, and I know that there's certain people who would help other people in church so I sent them a text message.... know her schedule so I know when she's gonna be coming home.... The other day someone called me and said: "Alice, do you know when Miss Brenda's gonna be home?" I was like, "I just dropped her off". "Good, thank you, I was worried about when she would get home". I knew it was some situation like that and they knew I wasn't gonna say anything 'cause they've used me before as their gobetween between people. A lot of people have used me in those situations.

Alice made two points that are worth highlighting. First, she was aware that she is a popular "go-between" specifically because she is discreet about the identity of the gift-giver. She would not tell me who in the congregation frequently gives to others; and her brow furrowed as she told me that she has been entrusted with that information and should not share it without permission. Clearly, members pay more than lip service to the idea that giving within the congregation should remain anonymous, and the level of secrecy speaks to how seriously members take not only their commitment to "give God the glory" but also to avoid relationships of giver and recipient. Secondly, however, Alice noted that there are "certain people who would help", suggesting both that inequality exists and that some people, at least, are aware of it. This is hardly surprising, given that members are tightly bound by shared social groups, workplaces, and neighborhoods. Notably, though, Alice inferred that knowledge of inequality is used at least partially to promote giving to those in need.

\section{Conclusion}

Full Truth teachings give religious meaning to financial practices. In some ways, they operate as an equal- izer, discouraging educational or economic advancement that would place members outside church community norms. Church teachings also encourage members to provide one another with important-and anonymousmaterial assistance that mitigates the financial risk faced by working class families. Though believers speak of thanking only God for this support, many are acutely aware of the social effort that has gone into obscuring the identity of those offering help. While such steps would seem to be "human efforts" rather than God's work, members understand the very process of obscuring one's identity as letting God's will shine through.

It is important to reiterate that though there is relatively little socioeconomic inequality within the church community, Full Truth members do experience the challenges of their working-class position relative to the rest of society. Members keep tight budgets, cooking at home, buying second-hand goods, and swapping items (often by posting them on the social media platform Instagram and waiting for a church member to comment that they want the item). They live in small homes and take modest vacations to local destinations. However, members' religious beliefs also allow them to avoid some of the most common high cost components of American life, such as health insurance and home mortgages. By emphasizing the religious importance of trusting God for their health and wealth, members both ensure their social class location and explain it in spiritual terms.

Thinking more broadly about social disparities and religious belief, this study suggests that faith can play a significant role in both the creation and amelioration of inequality. Though Full Truth members are unusual in the strictness of their beliefs concerning the relationship between God and financial well-being, faith in God to care for congregants' needs is a common theme in many conservative Protestant communities. Though this faith may ease members' financial worries by lending religious meaning to their situation, it does not ultimately help them get ahead. Looking at how this community handles social inequality through a religious framework suggests that we would do well to examine the hidden scripts that inform inequality in other settings, both religious and secular. In particular, the use of community (i.e., religious) values to mitigate tensions in socially meaningful ways may be a template for exploring the management of inequality in other contexts.

\section{Acknowledgments}

I would like to thank Melissa Wilde for her thoughtful guidance throughout this project. Special thanks also to Annette Lareau for her helpful feedback and support. Finally, I am deeply appreciative of the time and friendship I received from current and former members of Full Truth Calvary Church. This study was supported with funding from the Religious Research Associations' Constant A. Jacquet Award, the Society for the Scientific Study of Religion's Student Research Award, and the 
University of Pennsylvania's Graduate and Professional Student Association's Provost Fellowship for Interdisciplinary Innovation.

\section{Conflict of Interests}

The author declares no conflict of interests.

\section{References}

Ammerman, N. T., \& Farnsley, A. E. (1997). Congregation and community. New Brunswick: Rutgers University Press.

Barker, D. C., \& Carman, C. J. (2000). The spirit of capitalism? Religious doctrine, values, and economic attitude constructs. Political Behavior, 22(1), 1-27.

Beyerlein, K. (2004). Specifying the impact of conservative Protestantism on educational attainment. Journal for the Scientific Study of Religion, 43(4), 505-518.

Brooks, A. C. (2003). Religious faith and charitable giving. Policy Review, 2003(121), 39-50.

Chaves, M. (2004). Congregations in America. Cambridge, MA: Harvard University Press.

Chusmir, L. H., \& Koberg, C. S. (1988). Religion and attitudes toward work: A new look at an old question. Journal of Organizational Behavior, 9(3), 251-262.

Cobb, R. J., Perry, S. L., \& Dougherty, K. D. (2015). United by faith? Race/ethnicity, congregational diversity, and explanations of racial inequality. Sociology of Religion, 76(2), 177-198.

Darnell, A., \& Sherkat, D. E. (1997). The impact of Protestant fundamentalism on educational attainment. American Sociological Review, 62(2), 306-315.

Demerath, N. J. (1965). Social class in American Protestantism. Chicago, IL: McNally.

DeYoung, C. P., Emerson, M. O., \& Yancey, G. (2004). United by faith: The multiracial congregation as an answer to the problem of race. New York, NY: Oxford University Press.

Dougherty, K. D. (2003). How monochromatic is church membership? Racial-ethnic diversity in religious community. Sociology of Religion, 64(1), 65-85.

Dougherty, K. D., \& Huyser, K. R. (2008). Racially diverse congregations: Organizational identity and the accommodation of differences. Journal for the Scientific Study of Religion, 47(1), 23-44.

Dudley, C. S., \& Roozen, D. A. (2001). Faith communities today: A report on religion in the United States today. Hartford, CT: Hartford Institute for Religion Research.

Edgell, P., \& Tranby, E. (2007). Religious influences on understandings of racial inequality in the United States. Social Problems, 54(2), 263-288.

Emerson, M. O., \& Kim, K. C. (2003). Multiracial congregations: An analysis of their development and a typology. Journal for the Scientific Study of Religion, 42(2), 217-227.

Emerson, M. O., \& Smith, C. (2000). Divided by faith:
Evangelical religion and the problem of race in America. New York, NY: Oxford University Press.

Emerson, M. O., Smith, C., \& Sikkink, D. (1999). Equal in Christ, but not in the world: White conservative Protestants and explanations of black-white inequality. Social Problems, 46(3), 398-417.

Emerson, M. O., \& Woo, R. M. (2010). People of the dream: Multiracial congregations in the United States. Princeton, NJ: Princeton University Press.

Gittell, R., \& Tebaldi, E. (2006). Charitable giving: Factors influencing giving in U.S. states. Nonprofit and Voluntary Sector Quarterly, 35(4), 721-736.

Glassman, L. W. (2018). "In the lord's hands": Healing and embodiment in a fundamentalist Christian church. Sociology of Religion, 79(1), 35-57.

Havens, J. J., O'Herlihy, M. A., \& Schervish, P. G. (2006). Charitable giving: How much, by whom, to what, and how. In W. Powell \& R. Steinberg (Eds.), The nonprofit sector: A research handbook (pp. 542-567). New Haven, CT: Yale University Press.

Keister, L. A. (2003). Religion and wealth: The role of religious affiliation and participation in early adult asset accumulation. Social Forces, 82(1), 175-207.

Marsden, G. M. (1991). Understanding fundamentalism and evangelicalism. Grand Rapids, MI: W.B. Eerdmans.

Massengill, R. P. (2011). Why evangelicals like Wal-Mart: Education, region, and religious group identity. Sociology of Religion, 72(1), 50-77.

McConkey, D. (2001). Whither Hunter's culture war? Shifts in evangelical morality, 1988-1998. Sociology of Religion, 62(2), 149-174.

McPherson, M., Smith-Lovin, L., \& Cook, J. M. (2001). Birds of a feather: Homophily in social networks. Annual Review of Sociology, 27(1), 415-444.

Niebuhr, H. R. (1929). The social sources of denominationalism. New York, NY: Holt.

Perry, S. L. (2013). Racial diversity, religion, and morality: Examining the moral views of multiracial church attendees. Review of Religious Research, 55(2), 355-376.

Regnerus, M. D., Smith, C., \& Sikkink, D. (1998). Who gives to the poor? The influence of religious tradition and political location on the personal generosity of Americans toward the poor. Journal for the Scientific Study of Religion, 37(3), 481-493.

Reimer, S. (2007). Class and congregations: Class and religious affiliation at the congregational level of analysis. Journal for the Scientific Study of Religion, 46(4), 583-594.

Schaltegger, C. A., \& Torgler, B. (2010). Work ethic, Protestantism, and human capital. Economics Letters, 107(2), 99-101.

Schieman, S., \& Jung, J. H. (2012). "Practical divine influence": Socioeconomic status and belief in the prosperity gospel. Journal for the Scientific Study of Religion, 51(4), 738-756.

Schwadel, P. (2002). Testing the promise of the churches: 
Income inequality in the opportunity to learn civic skills in Christian congregations. Journal for the Scientific Study of Religion, 41(3), 565-575.

Schwadel, P. (2009). Neighbors in the pews: Social status diversity in religious congregations. Interdisciplinary Journal of Research on Religion, 5(2), 2-24.

Schwadel, P., \& Dougherty, K. D. (2010). Assessing key informant methodology in congregational research. Review of Religious Research, 51(4), 366-379.

Smith, C., \& Faris, R. (2005). Socioeconomic inequality in the American religious system: An update and assessment. Journal for the Scientific Study of Religion, 44(1), 95-104.

Souders, M. C. (2011). A god of wealth: Religion, modernity, and the rhetoric of the Christian prosperity gospel (Unpublished Doctoral dissertation). University of Kansas, Lawrence, Kansas.

Sullivan, S. C. (2012). Living faith: Everyday religion and mothers in poverty. Chicago, IL: University of Chicago Press.

\section{About the Author}

Lindsay W. Glassman is a Doctoral candidate in the Sociology Department at the University of Pennsylvania. Her work addresses religion, inequality, and health. She is currently writing her dissertation, which explores parents' medical decisionmaking, including the choice to avoid biomedical interventions in favor of either religious or secular alternative treatments.
Weber, M. (2002). The Protestant ethic and the "spirit" of capitalism and other writings. New York, NY: Penguin. (Original work published 1930)

Wilde, M., \& Glassman, L. W. (2016). How complex religion can improve our understanding of American politics. Annual Review of Sociology, 42(1), 407-425.

Wuthnow, R. (2003). Overcoming status distinctions? Religious involvement, social class, race, and ethnicity in friendship patterns. Sociology of Religion, 64(4), 423-442.

Yancey, G. (1999). An examination of the effects of residential and church on racial attitudes of whites. Sociological Perspectives, 42(2), 279-304.

Yancey, G., \& Kim, Y. J. (2008). Racial diversity, gender equality, and SES diversity in Christian congregations: Exploring the connections of racism, sexism, and classism in multiracial and non-multiracial churches. Journal for the Scientific Study of Religion, 47(1), 103-111. 